\title{
Human Factor in Equipment Safety of Hard Disk Manufacturing
}

\author{
Arshad Ahmad ${ }^{a *}$, Phooi Ling Yeoh ${ }^{a}$, Mohamad W Ali $^{a}$, Adnan Ripin $^{a}$, Saharudin Haron $^{\mathrm{a}}$ \\ Institute of Hydrogen Economy, Faculty of Chemical Engineering, Universiti Teknologi Malaysia, 81310 UTM Johor Bahru, Johor, Malaysia
}

*Corresponding author: arshad@cheme.utm.my

\section{Article history}

Received :28 May 2012

Received in revised form $: 2$ October

2012

Accepted :5 December 2012

Graphical abstract

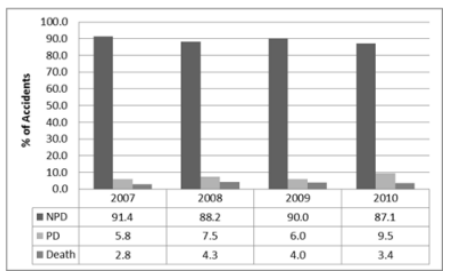

Abstract

The focus of this paper is on the human factors aspect of equipment safety focusing on process hazard analysis and safety programs. The objectives of this study are to determine the level of awareness, involvement and perceptions on occupational safety and health among workers. These are accomplished by conducting a survey using questionnaire and interviews involving 98 respondents in two hard disk manufacturing companies. Majority of the respondents were executives with high academic qualifications and possessed high level of safety awareness. The results conclude that despite the existence of various legislations, human factors and its interactions with facilities and management system is the main contributor to incidents. It is also found that most of the incidents involved power driven machineries. For the improvement of equipment safety, it is recommended that Process Hazard Analysis techniques be used to play significant role, along with both engineering and administrative control measures and safety programs.

Keywords: Equipment safety; industrial incidents; process hazard analysis; hard disk industry

(C) 2012 Penerbit UTM Press. All rights reserved.

\subsection{INTRODUCTION}

Malaysia has made significant progress in the manufacturing sector since its introduction in the 1970's. 1n 2010 the manufacturing sector contributed $27.6 \%$ of the GDP, and $3 \%$ of GDP growth, almost half of the total growth of $7.2 \%$ [1]. The electrical and electronic sector represented $29 \%$ of the total contribution of the manufacturing sector to the country's economy. With such an important contribution, the standards of occupational safety and health (OSH) among workers are to be addressed earnestly to ensure sustainability. This is realized through the Occupational Safety and Health Act (OSHA) 1994, and with its regulations. Using the new format of accidents reporting introduced in 2007, resulting from the Notification of Accident, Dangerous Occurrence, Occupational Poisoning and Occupational Disease (NADOPOD) Regulation 2004, accidents data are reasonably well-documented by relevant parties. This facilitates research works on occupational safety in Malaysia.

Figure 1 shows the accident statistics for the period between 2007 and 2010 [2] showing manufacturing as the main sector with a record of about two third of the total reported accidents. Following a downhill trend for the first 3 years, 2010 recorded a slight increase in reported accidents. Based on the data illustrated in Figure 2, out of the total accidents occurring each year, $85 \%$ $90 \%$ involves non-permanent disability (NPD) injuries. Although the percentage for higher consequence is lower, i.e., 5.8\%-9.5\% for injuries with permanent disability and $2.8 \%-4.3 \%$ for fatality, the number is still significantly high.

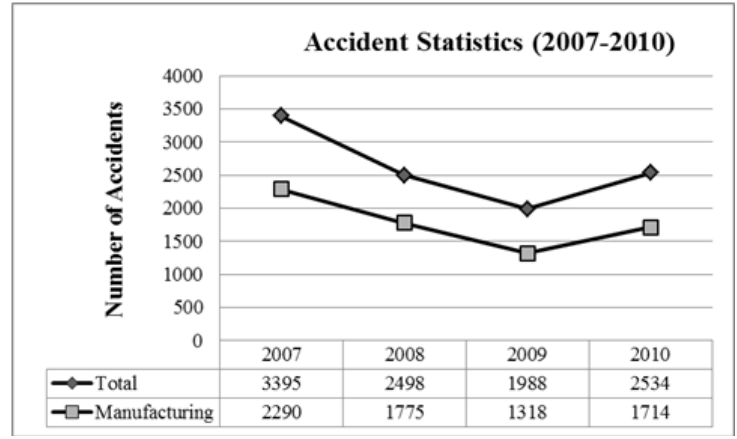

Figure 1 Accident Statistics in Malaysia (2007-2010)

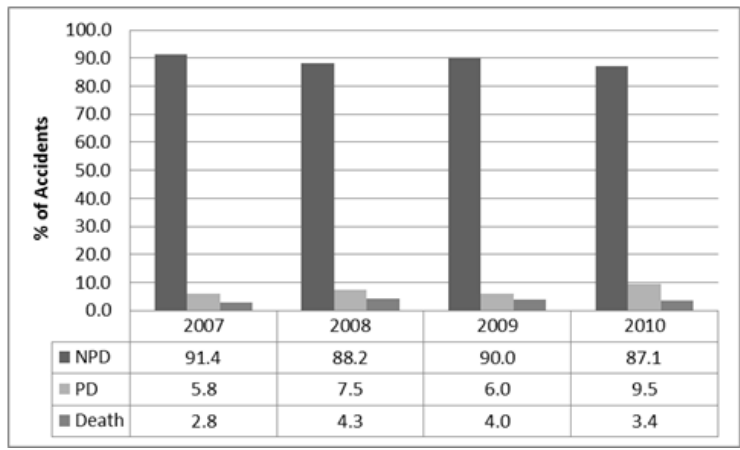

Figure 2 Breakdown for accidents in manufacturing sector in Malaysia 
By and large, there could be many contributors to industrial incidents including the lacking of design configuration, weakness in installation leading to difficulties in equipment handling, defects in manufacturing of the installed components, lack of maintenance and etc.

However, human factors could be the prime contributor to industrial accidents considering its inevitable human roles in each of the above tasks, hence the focus of the paper. Examples are plentiful and could be observed in aviation and maritime industry where $70 \%$ of accidents were due to human [3]. Statistics show that majority of accidents and incidents (over 80\%) in the chemical and petrochemical industries are contributed by human failure as a main and primary cause [3]. Taking manufacturing industry as a whole, research suggests that human error contributes to unsafe practices and accidents encompassing more than two third of the total cases of accidents [4]. Human factors are also frequently cited as the initiator of error-events which leads to incidents in the hazardous industries such as the chemical, oil and gas, rail or nuclear. It is therefore important to properly understand various human factors issues such as the organizational provision and culture, in addition to management of change, adequacy of operating procedures, training and incident investigation to ensure safety at work place [5].

It is by no means different in Malaysia where human factor could be the major contributor to industrial incidents. However, reported works on this matter are scarce. The study by Hussin and co-workers [6] on small and medium-sized food processing industries revealed that the main cause of incidents was human factors, where employers seldom took serious attentions on accidents at the workplace. This paper discusses the results of the survey carried out on two similar manufacturing plants on the level of awareness, involvements and perceptions of workers towards occupational safety issues relevant to their workplace. Among others, the focus is on human factors, Process Hazard Analysis (PHA) and safety programs.

\subsection{SAFETY ISSUES IN HARD DISK INDUSTRIES}

\subsection{Process Description}

Hard disk manufacturing process can be divided into two major sections, i.e., the front-end processing to produce polished substrates and the back-end processing that transforms the substrates into finished products. Figure 3 illustrates the typical front-end hard disk process flow. The activities carried out in each step of the process flow and equipment involved are shown in Table 1.

In the cassette exchanger, products are transferred into the process cassettes from the receiving cassettes, are then grouped according to different thickness in the groupers, followed by the electro-plating process. The plated products are then polished using slurries by the polishers and cleaned in the cleaning machines. The cleaned product is then subjected to inspection before being bagged for shipping.
Table 1 Substrate manufacturing activities and machine/equipment

\begin{tabular}{|c|c|c|}
\hline Process Flow & Activities & Machine/ Equipment \\
\hline Cassette Exchange & $\begin{array}{lr}\text { Products } & \text { are } \\
\text { transferred into } & \text { inocess cassettes from } \\
\text { proceiving cassettes } & \end{array}$ & Cassette Exchangers \\
\hline Grouping & $\begin{array}{l}\text { Products are grouped } \\
\text { according to different } \\
\text { thickness }\end{array}$ & Groupers \\
\hline Plating & $\begin{array}{l}\text { Products are plated } \\
\text { using electro-plating } \\
\text { process }\end{array}$ & $\begin{array}{l}\text { Plating Line with } \\
\text { tanks }\end{array}$ \\
\hline Polishing & $\begin{array}{l}\text { Products are polished } \\
\text { by using slurry }\end{array}$ & Polishers \\
\hline Cleaning & $\begin{array}{l}\text { Products are cleaned } \\
\text { from contaminants }\end{array}$ & $\begin{array}{l}\text { Cleaning Machines } \\
\text { with washer and } \\
\text { dryers }\end{array}$ \\
\hline $\begin{array}{l}\text { Testing } \\
\text { Certification }\end{array}$ & $\begin{array}{l}\text { Automated Inspection } \\
\text { is carried out as the } \\
\text { final test }\end{array}$ & $\begin{array}{l}\text { Automated Optical } \\
\text { Instruments (AOI) }\end{array}$ \\
\hline Bagging \& Shipping & $\begin{array}{l}\text { Products are bagged } \\
\text { in the shipping } \\
\text { cassettes and sent to } \\
\text { warehouse for } \\
\text { shipping }\end{array}$ & $\begin{array}{l}\text { Conveyors } \\
\text { Sealers }\end{array}$ \\
\hline
\end{tabular}

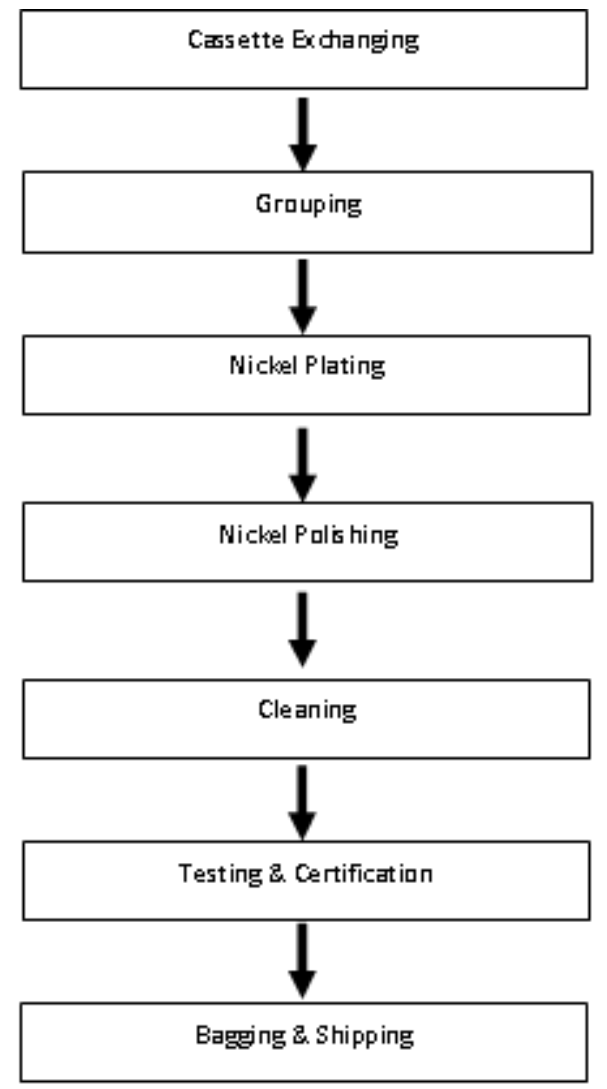

Figure 3 Typical front-end hard disk process flow

\subsection{Machinery Hazard}

Industrial Accident Prevention Association [7] identified safety and health hazard caused by machine as presented in Table 2 : 
Table 2 IAPA identified machinery hazard

\begin{tabular}{ll}
\hline Safety Hazard & Health Hazard \\
\hline Contact with moving parts & Contact with harmful chemicals \\
Contact with electricity, heat, fire, & $\begin{array}{l}\text { Contact with harmful noise, } \\
\text { radiation and vibration }\end{array}$ \\
cold and other energies & $\begin{array}{l}\text { Lack of adequate workplace } \\
\text { ergonomics : handling and process } \\
\text { design }\end{array}$ \\
Contact with pressurized liquid or & $\begin{array}{l}\text { Harmful action to the environment } \\
\text { and community }\end{array}$ \\
\hline
\end{tabular}

For the plants considered in this study, machinery hazards can be listed according to the workers' activities carried out at respective equipment, and is summarized in Table 3 . The tabulated potential occupational safety and health hazards are gathered from the selected substrate plants. Since automated equipment are used in most process, higher safety risks are more probable during preventive maintenance and troubleshooting where the equipment safety features might be switched off.

Table 3 Potential safety and health hazards of substrate manufacturing equipment

\begin{tabular}{|c|c|c|c|}
\hline Equipment & Activities & $\begin{array}{l}\text { Safety } \\
\text { Hazards }\end{array}$ & $\begin{array}{l}\text { Health } \\
\text { Hazards }\end{array}$ \\
\hline $\begin{array}{l}\text { Cassette } \\
\text { Exchangers }\end{array}$ & 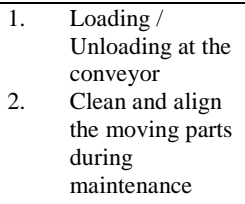 & $\begin{array}{lr}\text { Contact } & \text { with } \\
\text { moving } & \text { parts } \\
\text { such } & \text { as } \\
\text { conveyor } & \end{array}$ & $\begin{array}{l}\text { Ergonomic } \\
\text { with } \\
\text { repetitive } \\
\text { movement }\end{array}$ \\
\hline Groupers & $\begin{array}{l}\text { 1. Loading / } \\
\text { Unloading at the } \\
\text { conveyor } \\
\text { 2. Clean and align } \\
\text { the moving parts } \\
\text { during } \\
\text { maintenance }\end{array}$ & $\begin{array}{l}\text { Contact with } \\
\text { moving parts }\end{array}$ & $\begin{array}{l}\text { Ergonomic } \\
\text { hazard } \\
\text { with } \\
\text { repetitive } \\
\text { movement }\end{array}$ \\
\hline Plating Line & $\begin{array}{ll}\text { 1. } & \begin{array}{l}\text { Cleaning of } \\
\text { plating line }\end{array} \\
\text { 2. } & \begin{array}{l}\text { Troubleshooting } \\
\text { of damaged parts }\end{array}\end{array}$ & 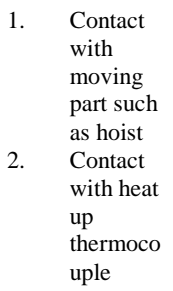 & $\begin{array}{l}\text { Chemical } \\
\text { Exposure }\end{array}$ \\
\hline Polishers & $\begin{array}{l}\text { 1. } \begin{array}{l}\text { Manual loading / } \\
\text { unloading of } \\
\text { products onto the } \\
\text { polisher }\end{array} \\
\text { 2. } \\
\text { Troubleshooting } \\
\text { and Preventive } \\
\text { maintenance }\end{array}$ & $\begin{array}{l}\text { Crashing } \\
\text { of upper } \\
\text { platen } \\
\text { onto } \\
\text { workers } \\
\text { Caught } \\
\text { in } \\
\text { between } \\
\text { upper \& } \\
\text { lower } \\
\text { platen }\end{array}$ & $\begin{array}{l}\text { Chemical } \\
\text { Exposure }\end{array}$ \\
\hline $\begin{array}{l}\text { Cleaning } \\
\text { Machines }\end{array}$ & $\begin{array}{ll}\text { 1. } & \begin{array}{l}\text { Troubleshooting } \\
\text { of damaged parts }\end{array} \\
\text { 2. } & \begin{array}{l}\text { Preventive } \\
\text { maintenance }\end{array}\end{array}$ & $\begin{array}{l}\text { Caught } \\
\text { between } \\
\text { moving parts }\end{array}$ & $\begin{array}{l}\text { Chemical } \\
\text { Exposure }\end{array}$ \\
\hline $\begin{array}{l}\text { Automated } \\
\text { Optical } \\
\text { Instruments } \\
\text { (AOI) }\end{array}$ & $\begin{array}{l}\text { 1. Align the laser } \\
\text { 2. Align moving } \\
\text { parts }\end{array}$ & $\begin{array}{l}\text { Caught } \\
\text { in } \\
\text { between } \\
\text { moving } \\
\text { parts } \\
\text { Hit by } \\
\text { robotic } \\
\text { arm }\end{array}$ & $\begin{array}{l}\text { Radiation } \\
\text { exposure - } \\
\text { laser (loss } \\
\text { of eye } \\
\text { sight) }\end{array}$ \\
\hline
\end{tabular}

\subsection{METHODOLOGY}

\subsection{Plant Description}

Two major hard disk factories were selected, both producing similar products and using similar equipment. Following a preliminary study by interviews and site visits to identify major safety issues and safety related programs implemented, data requirement was determined and survey questionnaires were designed. The previous incident statistics and safety programs were obtained from the company records. Since the substrate cutting and grinding processes are not common to both factories, these processes were excluded from the study.

\subsection{Design of Questionnaire}

The questionnaire was divided into five sections. The first part focuses on the respondent's background, while the remaining sections address issues of equipment handling and safety in the factories including the respondents' awareness on the various types of risk assessment and its application in their factories as well as current safety equipment issues. Multiple choice questions were used, but in some questions, the respondents were required to provide ratings based on Likert's 5-Level Scale of 1 (Disagree) to 5 (Strongly Agree). Based on these ratings, the average indices were computed using the following equation.

$$
\text { Average index }=\frac{\sum \mu n}{N}
$$

Here, is the weightage given to each factor by the respondent, $n$ is the frequency of the respondents and $N$ is the total number of respondents.

As recommended by Abd Majid and McCaffer [8], rating scales were determined to indicate agreement (Table 4) and improvement (Table 5). Pearson Correlation Coefficients were computed using the Statistical Analysis Package SPSS to test hypotheses. An $r$ value nearing 1 shows strong correlation between the variables and a $p$ value 0.05 indicates that the Pearson is significant.

Table 4 Rating scale for agreement average index

\begin{tabular}{ll}
\hline Rating & Average index \\
\hline 1 = Strongly Disagree & $(1.00 \leq$ Average Index \\
& $<1.50)$ \\
2 = Disagree & $(1.50 \leq$ Average Index \\
& $<2.50)$ \\
3 = Neutral & $(2.50 \leq$ Average Index \\
& $<3.50)$ \\
$4=$ Agree & $(3.50 \leq$ Average Index \\
& $<4.50)$ \\
5 = Strongly Agree & $(4.50 \leq$ Average Index \\
& $<5.00)$ \\
\hline
\end{tabular}

\subsection{Data Collection}

Based on the recommendation by Bartlett [9], the sample size was determined using Cochran relationships [10], and for a population of 400 , a minimum of 92 respondents were required. For convenience, 50 workers were selected from each company, thus giving a total of 100 respondents. This purposive sampling was 
designed to include those who were mostly involved in either equipment handling or process hazard analysis. In addition, interviews were conducted to clarify inconsistencies in responses. When further information involving incidents were required, the safety and health officials and equipment personnel were consulted.

Table 5 Rating Scale for average improvement index

\begin{tabular}{ll}
\hline Rating & Average index \\
\hline $0=$ Never & $(0.00 \leq$ Average Index \\
& $<1.00)$ \\
$1=$ Little & $(1.00 \leq$ Average Index \\
& $<1.50)$ \\
& $(1.50 \leq$ Average Index \\
& $<2.50)$ \\
& $(2.50 \leq$ Average Index \\
& $<3.50)$ \\
& \\
$4=$ Good & $(3.50 \leq$ Average Index \\
& $<4.00)$ \\
\end{tabular}

\subsection{RESULTS AND DISCUSSION}

\subsection{Background of the Respondents}

The survey was conducted at two companies, i.e., company 1 and 2. The former was commissioned in 2007 and the latter (i.e., company 2) has been in operation since the year 2000. Majority of the respondents have worked for more than a year and should be able to provide constructive feedbacks (see Table 6).

Table 6 Respondent demography - number of years in employment

\begin{tabular}{llllll}
\hline Years in & $<\mathbf{1}$ & $\mathbf{1 - 5}$ & $\mathbf{6 - 1 0}$ & $>\mathbf{1 0}$ & Total \\
Service & year & years & years & years & \\
\hline Company 1 & 10 & 40 & 0 & 0 & 50 \\
Company 2 & 7 & 27 & 11 & 3 & 48 \\
\hline
\end{tabular}

The respondents were selected from among those who were either actually handling the equipment and/or involved in incident investigations to guarantee general understanding of the issues to be discussed. Of the total 98 respondents, $29.3 \%$ were from the process or engineering section, $34.35 \%$ were handling equipment, $11.11 \%$ were from manufacturing, $7.7 \%$ from quality assurance, $6.6 \%$ from the safety and health and $11.1 \%$ were from other sections. In terms of job responsibility, $82.84 \%$ were engineers or executives, $9.9 \%$ were managers and senior engineering positions, $2.2 \%$ from the top management and $2.5 \%$ were nonexecutives. As a whole, the respondents were mostly executives (or higher) with high academic qualifications

\subsection{Nature of Equipment Incidents}

Table 7 shows the total incidents reported, with polisher (51\%) involving highest number of incidents, followed by plating operators $(22 \%)$ and cleaning machines operators $(13 \%)$. Similarly, the highest number of injuries was also involving polishers, (28 cases) followed by the operator of cleaning machines (12 cases). Smaller number of incidents was reported on Grinders and Grouper machines (both contributed $3 \%$ each), as the activities involved only loading and unloading of products at conveyors. The results conclude that power driven machineries dominate the incidents. This is consistent with the study conducted on accidents in the Korean manufacturing industry [11].

Other non-production equipment contributing to the incident statistics were wastewater treatment equipment and testing equipment. Moreover, interviews with the Safety and Health official of the organizations revealed that only operators and technicians were involved in accidents with injury.

Table 7 Equipment incidents according to types of equipment

\begin{tabular}{|c|c|c|c|c|c|}
\hline \multirow[b]{2}{*}{$\begin{array}{l}\text { Types of } \\
\text { Equipment }\end{array}$} & \multicolumn{3}{|c|}{ Types of Incidents } & \multicolumn{2}{|c|}{ Total Incidents } \\
\hline & $\begin{array}{l}\text { Near } \\
\text { Miss } \\
\text { (no } \\
\text { injury) }\end{array}$ & $\begin{array}{l}\text { Accident } \\
\text { with } \\
\text { injury }\end{array}$ & Fatality & Number & Percentage \\
\hline Grinder & 3 & 0 & 0 & 3 & $3 \%$ \\
\hline Grouper & 0 & 3 & 0 & 3 & $3 \%$ \\
\hline Plating & 15 & 5 & 0 & 20 & $22 \%$ \\
\hline Polisher & 18 & 28 & 0 & 46 & $51 \%$ \\
\hline $\begin{array}{l}\text { Cleaning } \\
\text { machines } \\
\text { (with } \\
\text { washer / } \\
\text { dryer) }\end{array}$ & 0 & 12 & 0 & 12 & $13 \%$ \\
\hline Others & 3 & 3 & 0 & 6 & $7 \%$ \\
\hline Total & 39 & 51 & 0 & 90 & $100 \%$ \\
\hline
\end{tabular}

Having been in operation for several years, the frequency of incidents for Company 2 is now low, with less than 10 incidents per year. To provide direct comparison, data for the first three years of operation were used (See Figure 4). Similar for both companies, incidents with injuries were dominated by workers being caught in between and struck by object. Near misses were mostly chemical related (50\% in company $2,90.2 \%$ in company 1). Moreover, there was no consistency on increment or decrement of incidents throughout the early years, but Company 1 recorded more incidents.

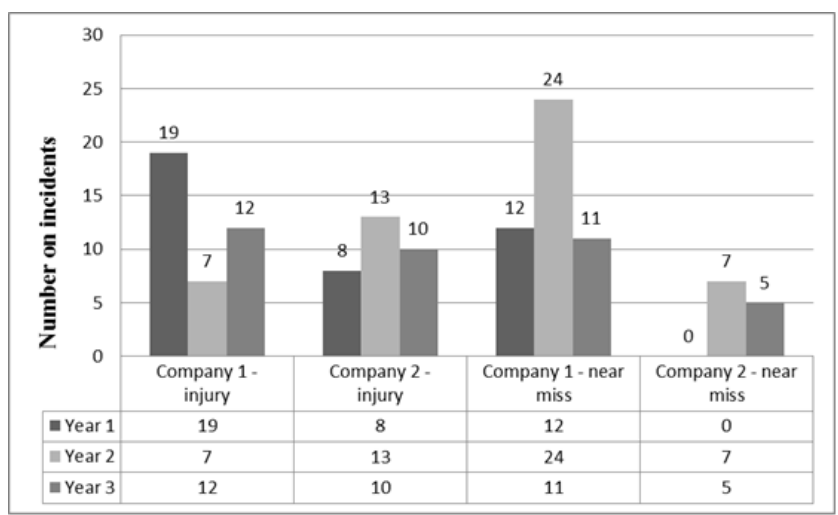

Figure 4 Incident data for first 3 years of operation 


\subsection{Root Causes of Equipment Incidents}

Majority of the respondents also believed (average index of 4.2) that the root causes of the accidents were related to human factors such as carelessness, fatigue, negligence or lack of awareness. Other factors include inadequate equipment safety features, inadequate procedures and instructions, inadequate training and lack of supervision. Nevertheless the average indices obtained were in the vicinity of 3.0.

Similar observations have also been observed in a study involving eleven companies in Jordan [12]. It is therefore important to manage human factors (specifically human errors) by implementing engineering control mechanisms such as automation, installation of guarding, interlock and alarms systems as well as various sensors and indicators for relevant task functions.

\subsection{Process Hazard Analysis}

Process hazard analysis (PHA) is now becoming applicable to manufacturing industries in Malaysia. In the survey, $64 \%$ of the respondents have carried out PHA. For both companies, Failure Mode and Effect Analysis (FMEA) is the most preferred method (75\% for Company 1, $90 \%$ in Company 2 and $83 \%$ overall) and Hazard and Operability (HAZOP) study is carried out only selectively on certain equipment (19\% for Company 1 and $10 \%$ for Company 2). Testing or support equipment are normally exempted from PHA along with equipment perceived to have negligible risk. The survey also revealed that PHA contributed significantly towards increasing the understanding of equipment safety requirement.

Figure 5 shows the frequency of the PHA being carried out on equipment. The frequency for newly installed equipment was almost the same for less than 6 months, 6 months to 1 year, every year and more than 1 year. For older equipment, PHA was carried on yearly basis.

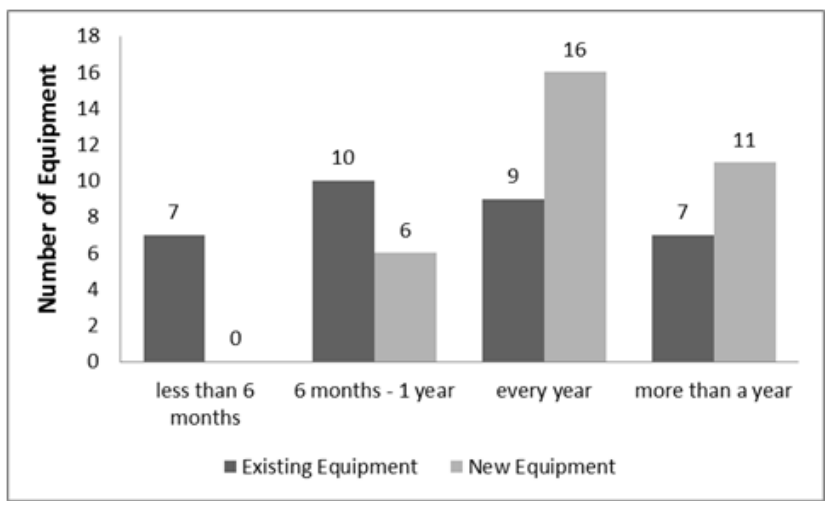

Figure 5 Frequency of risk assessment being carried out

Implementing PHA in process plant is beneficial not only in terms of providing useful insights for control measures, but also facilitating human factors positively towards safety. This is especially true in processing plant where better understanding on how to synchronize and improve the human factor with engineering practices can be achieved to prevent recurrence of similar incidents. By integrating human factor with process hazard analysis, it will help to identify, understand, control and prevent human related failure which can result in an incident or accident during operation of chemical processing plant [3].

\subsection{Control Measures}

Majority of the respondents $(83.7 \%)$ were required to handle variety of equipment in their daily duties. Of these, $65 \%$ have used 1-5 different types, $6 \%$ with 6-10 types and $29 \%$ have the experience with more than 10 types of equipment. The results also revealed that majority of the respondents agreed that control measures including safety training, equipment buyoff, safe work procedure and automation improved equipment safety. Pearson correlation show that equipment safety could be improved not only by conducting PHA, but also implementing other control measures, with $r=0.715$ for safety training, $r=0.477$ for equipment buyoff, $r=0.734$ for safe work procedure and, $r=0.450$ for automation. The $p$ value is $<0.45$ proved that the correlation was significant.

In addition, the use of administrative control measures such as training, equipment buyoff and safe work procedures can serve as positive reinforcement. This is because major accidents are typically resulting from combination of events including some previous actions and failures. Furthermore, the study by Mital and Pentatur [13] also revealed the importance of designing features within automation system that allow human supports to compensate for technological limitations.

\subsection{Safety Program}

The respondents have had the opinion that organizational safety programs such as safety training, safety campaign, equipment buyoff and safe work procedures would improve the equipment safety. The survey has recorded a score of higher than 3.5. Among these, safety training and safety campaign scored highest with $\mathrm{r}=0.647$ and 0.714 respectively. Establishing safety programs that integrate various units within the organization is an effective way to reduce equipment incidents since such integrations nurture better teamwork and commitment to the workplace. This is also the conclusion obtained by other researchers [14].

Although there is the perceived importance of management encouragement in establishing safety programs at work, the respondents have provided the results totally opposite in nature. This is probably due to the fact that only $60 \%$ of the respondents have had subordinates who would most unlikely be influenced in their decisions, all due to their high level of academic qualification and training.

\subsection{Safety Awareness}

The survey also revealed the high awareness on incidents occurrences where $91 \%$ of the respondents giving positive feedbacks. This is high when compared to their awareness on the companies' involvement with safety management system certification, which recorded lower values (50\% for company 2 and $70 \%$ for company 1 ), perhaps indicating that they are more concerned with employees, instead of the employer. A higher awareness for company 1 was expected as the company was already certified under OHSAS 18001.

\subsection{CONCLUSION}

A survey on safety related issues has been carried out in two hard disk manufacturing companies, involving 98 respondents. Majority of the respondents were executives with higher academic qualifications. Due to this fact, they have reasonable exposures to safety issues and high level of awareness. The results also conclude that despite the existence of various legislations, human 
factor and its interactions with facilities and management system is the main contributor to incidents. Some of the important conclusions based on the findings include:

(1) Power driven machineries dominate the incidents, in this case, incidents are dominated by polishing plating and cleaning machines.

(2) The major root cause of the accidents are related to human factors

(3) PHA contributed significantly towards increasing the understanding of safety requirement.

(4) Both engineering and administrative control measures improve equipment safety

(5) Safety programs such as safety training, safety campaign, equipment buyoff and safe work procedures improve equipment safety

\section{References}

[1] M. O. F. 2011. Ministry of Finance Malaysia Economic Report 2010/2011, Chapter 3. Retrieved on Nov 3, 2011 from http://www.bnm.gov.my

[2] Department of Occupational Safety \& Health. 2011. Statistic of the Department, Retrieved on Nov 3, 2011 from http://www.dosh.gov.my/wps/portal/

[3] Kariuki, S. G. and K. Lowe. 2007. Integrating Human Factor Into Process Hazard Analysis. Reliability Engineering and System Safety. 92: 1764-1773.

[4] Wilson-Donnelly, K. A., H. A. Priest, E. Salas and C. S. Burke, 2005 The Impact of Organizational Practices on Safety in Manufacturing: A
Review and Reappraisal. Human Factors and Ergonomics in Manufacturing \& Service Industries. 15(2): 135-176.

[5] Hughes, G. and K. Kornowa-Weichel. 2004. Whose Fault is it Anyway? A Practical Illustration of Human Factors in process Safety. Journal of Hazardous Materials. 30: 127-132.

[6] Hussin, Z., K. Jusoff, Y. J. Soon and K. K. Lai. 2008. Accidents in the Food-Manufacturing Small and Medium Sized Malaysian Industries. Asian Social Science. 4(8): 27-31.

[7] I. A. P. A. 2008. A Health and Safety Guideline You're Your Workplace - Machine Safety, Industrial Accident Prevention Association, May, 1-2.

[8] Abd Majid, M. Z. A., and R. McCaffer. 1997. Assessment of Work Performance of Maintenance Contractors in Saudi Arabia. ASCE Journal of Management in Engineering. 13: 91.

[9] Bartlett, J. E., J. W. Kotrlik and C. H. Chadwick. 2001.Organizational Research: Determining Appropriate Sample Size in Survey Research. Information Technology. Learning, and Performance Journal. 19(1):4350 .

[10] Cochran, W. G. 1977. Sampling Techniques. 3rd ed. New York: John Wiley \& Sons.

[11] Jeong, B. K. 1999. Comparisons of Variables Between Fatal and Nonfatal Accidents in Manufacturing Industry. International Journal of Industrial Ergonomics. 23: 565-572.

[12] Abu-Khader, M. M. 2004. Impact of Human behaviour on Process Safety Management in Developing Cuntries. Process Safety and Environmental Protection. 82: 431-437.

[13] Mital, A. and A. Pennathur. 2004. Advanced Technologies and Humans in Manufacturing Workplaces: An Interdependent Relationship. Int. Journal of Industrial Ergonomics. 33: 295-313.

[14] Nielsen, K. J., K. Rasmussen, D. Glasscock and S. Spangenberg. 2008. Changes in Safety Climate and Accidents at Two Identical Manufacturing Plants. Safety Science. 46: 440-449. 